\title{
Analysis of Monolaurin, Beta- Carotene, Weakened Beta-Carotene and their Antagonistic Properties with HIV: An Exploratory Study
}

\author{
Paul Inbaraj. \\ A. MSW. M.Sc., MBA. B.Ed., MA (Psy) \\ Bishop Cotton School, Shimla, Himachal Pradesh-171002
}

\begin{abstract}
The study is framed to find out the HDL variation, viral load obliteration, vulnerability in the oxidative stress with the introduction of pro-oxidants, HIV's RNA mutation in the selected HIV positive people or BLT mice with the combination of monolaurin and beta carotene, monolaurin and weakened beta carotene, in the presence of ART and Monolaurin and beta-carotene combinations, in the absence of ART and monolaurin and beta-carotene. The problems will be focused in the serological studies with the help of LC, HPLC, Cytometric techniques, Western Blot and genotyping test. The effect of the combination will be giving the status of CD4 counts in pre and posttest and it would be the major part to obtain the various results in the background of these combinations. The study is based on Exploration of missing links of monolaurin's viral properties and the limiting factor of monolaurin can work out with Beta carotene, either normal form or weakened form. Monolaurin sensitive to the LPS (Lipo Poly Saccharide) in the GST (Gastro intestinal Tract). That would be the base, to link up with the beta carotene, it need some support to penetrate to the LPS, this will be enhanced by the Beta carotene's properties either in the form of Antioxidant or Pro-oxidant. These combinations can create oxidative stress in the viral Nucleotides and make the RNA to mutate, so that that there will be no contact between host cells. To find out this study we will use the Western blot to compare the Protein sequences of normal HIV affected serum with the serum will have both combinations.
\end{abstract}

Keywords: HDL, Monolaurin, Beta-carotene, Weakened beta-carotene, Nicotine, CD4 cells, HIV, Western blot.

\section{Introduction}

HIV can escape from the immune system during its Seroconversion period (approximately 90 days 0r 3 months) by hiding itself in fat and its content. During seroconversion, you may not have detectable levels of HIV antibodies in your blood. An HIV blood test during this time could result in a false negative. That way it is camouflaged from the immune system. Especially triglycerides and other LDLs because fat contents in the body need more temperature to melt so that it would take an advantage in the host to proliferate. Over this period it cannot expose the virulent activity

HIV attacks white bloods cells known as T4 cells. The severity of the virus can be determined by measuring the number of T4 cells in the body. This is called a CD4 count. On average, a healthy individual will have a CD4 count between 535 and 1,145. HIV infected individuals usually have CD4 levels below normal. As the disease progresses, CD4 levels continue to drop.CD4/CD8 cell ratio: To obtain a better picture of disease progression, it is advisable to measure the CD4/CD8 cell ratio. The normal ratio is about 1 to 1.5. If the disease is progressing, CD4 will decline and CD8 will stay the same or increase and the CD4/CD8 ratio will be $<1$, indicating disease progression (Prof.Dr.Luc Restins).

\section{Quasi-species}

In each patient, more than 109 new viruses are produced every day! During the replication process, the enzyme reverse transcriptase, which transcribes the RNA into DNA, has a high error rate: for each 10,000 nucleotide conversions of RNA into DNA, 1 error occurs. Because there are about 104 nucleotide positions/genome, this rate can lead to $104 \mathrm{x}$ $10-4$ x $109=109$ mutations per day. Therefore, each new generation of viruses is slightly different from the previous ones, and this constant evolution helps HIV remain one step ahead of the immune system. (Prof.Dr.Luc Restins).

We know that HIV over-activates the immune system somehow; however, we do not know exactly how. A new theory is the "leaky gut" theory (Douek D. HIV disease progression: immune activation, microbes, and a leaky gut Top HIV Med. 2007 Aug-Sep;15(4):114-7 (abstract)). During acute HIV infection, the majority of all mucosal CD4 $\mathrm{T}$ lymphocytes are lost, especially in the gastrointestinal tract (GIT). Infection is associated with increased permeability of the GIT leading to increased circulating lipopolysaccharide (LPS) levels, a component of the cell wall of Gram-negative bacteria in the GIT. The circulating LPS cause chronic immune activation in a non-specific way. The chronic immune activation causes higher susceptibility to HIV because HIV needs activated CD4 T cells for replication. (Prof.Dr.Luc Restins).

It has been shown that antiretroviral therapy reduces plasma LPS, leading to greater CD4 $\mathrm{T}$ cell reconstitution. Antiretroviral treatment does not show any efficacy because it targets only replicating viruses. Nevertheless, the genetic matter (RNA) of HIV is unstable to oxidation rather DNA could withstand. So, it escapes from the oxidative stress and finding the host cell then it penetrate an enzyme that enables its genetic material to be integrated into the DNA of the infected cell.O2 is unique in that it is a relatively stable free radical with two unpaired electrons that have parallel spins. This feature restricts $\mathrm{O} 2$ to accept electrons one at a time and is used as an electron acceptor in electron transport

\section{Volume 4 Issue 11, November 2015}




\section{International Journal of Science and Research (IJSR) \\ ISSN (Online): 2319-7064 \\ Index Copernicus Value (2013): 6.14 | Impact Factor (2014): 5.611}

chains that are abundant in biological systems. The partial reduction of $\mathrm{O} 2$ leads to a cascade of oxygen-derived species that contribute to damaging cellular macromolecules, tissue injury, dysfunction, and disease.

RNA is even more prone to base oxidation than DNA. When, an oxidative stress exists in a certain period the RNA of retro virus will mutate and the genome will be depleted somewhat. This reason HIV cannot propagate inside the host rather it will be nullified in the system.

Moreover, opportunistic infections like Heart diseases also carried out by HIV. Serum cholesterol (HDL) level decreases in HIV affected people but triglycerides may increases in the blood, so they prone to heart disease. (Pub Med). Patients with HIV/ AIDS without ART presented an increase of triglyceride. (Pub med and LILACS data bases)

Earlier studies stated that the Lauric acid (Dodeocanoic acid) is extracted from the coconut oil, $50 \%$ carbon of the fatty acids in coconut oil is the 12 carbon lauric acid and 15 carbon Monolaurin can kill harmful pathogen like bacteria, fungi and virus. Lauric acid is a saturated fatty acid and it increases the serum cholesterol (HDL). Monolaurin acid work is pretty simple. Nature designed monolaurin acid specifically for melting the fat away from viruses so the immune system could recognize and destroy them.

Coconut oil is composed predominately of MCFAs and also alleviates many of the opportunistic infections that commonly afflict AIDS patients.

Viruses that are the most vulnerable to the killing action of medium chain fatty acids (MCFA) in coconut oil are those which are encased in a lipid membrane. When MCFA come into contact with these viruses, they are absorbed into their outer membranes, destabilizing them to the point that the membrane disintegrates, killing the virus.

Monolaurin: studies show there are no allergies, side effects or interactions with any drugs or nutrients with Monolaurin. It does not boost the immune system or affect any body system. Monolaurin is very safe to take. So, a person simply takes our Monolaurin until they are well. This can be as short as a few weeks for a simple bacterial infection to 4+ months for herpes, hepatitis, HIV, etc.

Maintenance Dose: Once the illness symptoms are gone, a person with a potentially re-occurring disease (herpes, etc.) can take a maintenance amount of 1 scoop a day to help prevent them. Re-occurrences occur when a virus or bacteria has burrowed in a cell were they are protected from monolaurin and drugs. At a later date, they can leave the cells looking to re-establish an active disease. This is especially a consideration with Lyme disease, CFS, Herpes, Shingles, Hepatitis and HIV.

People take the maintenance dose simply because then monolaurin is in their blood. If the disease comes out of hiding in the body cells, the monolaurin can come in contact with it and kill it before it can re-establish itself. What we mean by that is that monolaurin directly attacks all pathogen (bad) bacteria and many viruses without harming good bacteria or cells. It does this by a very simple method. All pathogen bacteria, and many viruses, have a lipid (fat) molecule membrane (skin, envelope) around them. Monolaurin is a similar size molecule and absorbs into the membrane and cell. When there, it does two things:

1) It interrupts the reproductive cycle and prevents the cell from multiplying, and

2) It weakens the membrane and, eventually, causes it to rupture, killing it.

The fact that monolaurin's activity is limited to lipid coated organisms (Virus) (Conrado S. Dayrit)

\section{HIV and Monolaurin Contact}

Many people have given up on an answer here. Monolaurin will kill HIV but it needs to come into contact with the virus to do so. Continue according to reduced symptoms, but an initial 4 months at full dose will help get rid of the active form and accompanying co-infections. (Bio-Fibrin is very helpful with HIV.) Then, HIV is a strong candidate for ongoing Maintenance amounts to fight re-occurring HIV virus. Monolaurin doesn't interrupt any other protocol and this is not a place to skimp! If test counts go lower but then start to level out, Bio-Fibrin might be essential to reduce any biofilms.(Inspired nutrition TM -Ultimate supplements \& disease protocols)

Beta Carotene-Here is stated that Monolaurin will kill HIV but it needs to come into contact with the virus to so. Studies suggested that Beta carotene is an antioxidant and can remove the free radicals. A number of epidemiological studies have reported associations of beta-carotene plasma levels or intake with decreased lung cancer risk (GoralczykPubMed). But B.L Baker et al., (PubMed) identified if smokers will consume more Beta carotene leads to Lung cancer. Because Beta-carotene weakened by Nicotine in the cigarette then it alters the Antioxidant characters. $\beta$-Carotene has been hypothesized to promote lung carcinogenesis by acting as a prooxidant in the smoke-exposed lung ( Daniel L Baker et al.,)

If a person normally intake the $\beta$-carotene it works as an antioxidant (those who are not smoke ) but the same $\beta$ carotene could promote lung cancer those who are addicted with smoking. Why there is two way approach in its character. Basically the nicotine is weakening the Beta carotene and it changes it features to Pro-oxidant.

HIVs are better to live in the environment of beta carotene because it would not fight with them instead it may protect the Viral RNA from Oxidative stress so that there is no RNA mutation takes place in the genome of HIV. While oxidative stress takes place in the Retroviral RNA it could not balance the stress rather it allows the genome to mutate, as a result damages in the A-U and G-T base pairs. So that, the integrase enzyme could not find a place to incorporate with host DNA.

Beta Carotene (C40H56 - Red- orange pigment) is biosynthesized from "geranyl geranyl pyrophosphate". The interesting fact is that Beta carotene absorbed in the

\section{Volume 4 Issue 11, November 2015}




\section{International Journal of Science and Research (IJSR) \\ ISSN (Online): 2319-7064}

Index Copernicus Value (2013): 6.14 | Impact Factor (2014): 5.611

presence of fat and it regulates cell growth. (Authority nutrition).

Here, i would like to suggest that Monolaurin can destroys the Virus but it needs into contact with the virus so. Monolaurin itself as a fat and can absorbs the Beta carotene very well.

Weakened Beta carotene would act as a prooxidant instead Antioxidant. Now we strengthen the monolaurin with betacarotene to contact with the virus to so. Nicotine can weaken the Beta carotene and it changes the $\beta$ - carotenes antioxidant property to Pro-oxidant. Nicotine and $\beta$ - carotene both are water soluble and it will easily uptake by monolaurin.

Pro-oxidant role of b-carotene in cells: analysis of oxidative markers b-Carotene has been shown to possess pro-oxidant properties in cell models, at least under certain circumstances (high oxygen tension, high carotenoid concentration, unbalanced intracellular redox status) (Palozza, 1998). Its pro-oxidant effects into the cells may be evidenced as a rough oxidative damage to the cell structures (DNA, lipids and proteins) or, otherwise, as a subtle modulation of redox-sensitive genes and transcription factors.

\section{Objectives}

1) To reduce the higher error in the viral RNA.

2) To prove that LPS level (Leaky gut theory) of virus in the gastro intestinal tract will no longer make the way to reduce the count of CD4.

3) Two ways defense and two ways attack will be facilitated save the count of CD4 cells from the LPS in a chronic immune reaction in GTP and allow more CD4 cells react with HIV rather than LPS.

4) To create an internal Oxidative stress on the Nucleotides of the HIV's RNA.

5) To ameliorate the host cell to avoid the contact of the HIV cells.

6) To create an internal mutation between the base pairs of HIV's RNA.'

7) To determine the drug combinations efficacy with or without ART.

8) To make a way to increase the HDL level with the help of Monolaurin and to nullify the virus (Proteins), assisted with Beta carotene.

9) To hold back the Monolaurin's limited properties with virus (Lipid Coated) and make it stronger to attack viral RNA

10) To enhance the killer properties of monolaurin with the combination of Beta carotene.

11) To prove that pro-oxidant properties of Beta carotene can extend the oxidative stress on the HIV's RNA and Viral Protein properties.

12) To allow monolaurin to absorb the fat soluble Beta carotene.

13) To prove with the help of Western blot that missing of glycoprotein shows that internal damage in the viral protein.

\section{Materials and Methods}

a) Blood Samples

Blood Samples will be collected from HIV positive people directly or from VCTC, ICTC or Government or private Hospitals. Collected samples would be stored in the Refrigerator (up to 42 days). At least five samples would be collected from the HIV positive people or five individuals (HIV affected) will be selected for this study.

b) Monolaurin

Monolaurin powder will be procured from the market (Grade: Pharmaceutical grade \& food grade- Molecular Weight 274.40).

c) Beta -carotene

Beta carotene $(536.8726 \mathrm{~g} / \mathrm{mol})$ Liquid or soft gel form will be procured from the market.

d) Nicotine -

Nicorette Gum or Thrive Gum / Nicotine 10.0\% wt/vol diluted with vegetal glycerine

e) Subjects to be selected

1. Individual affected with HIV/ AIDS: At least five individuals will be selected for this study. First of all we would ask the willingness of an individual to incessantly attend this research. If he could do willingly it will reinforce the study.

2. Humanized mice for this Projected study: The term "humanized mice" has been applied to a variety of mouse models: (a) mice that have a single or multiple human transgene(s) in an otherwise wild-type animal, (b) immune deficient mice transplanted with human cells or implanted with normal or diseased human tissues, (c) $\mathrm{CD}_{4} 4^{+}$ hematopoietic progenitor cell engrafted immune deficient mice and $(\mathrm{d})$ various combinations of $\mathrm{a}, \mathrm{b}$, and $\mathrm{c}$. Humanized BLT mice are individually bioengineered by bone marrow transplant of $\mathrm{CD} 4^{+}$hematopoietic progenitor cells into immunodeficient mice previously implanted with autologous liver and thymus tissue (Human hematopoietic cells are present in all tissues of BLT mice, including peripheral blood, primary lymphoid tissues, secondary lymphoid tissues, and mucosal tissues (Paul W Denton et al.,)

\section{There are different HIV antibody tests available, such} as:

- Enzyme-linked immunosorbent assay (ELISA), high sensitivity, used in laboratories

- Rapid tests can be used in all settings and offer fast results

- Western blot, high specificity, used as an HIV confirmation test

f) Introduction of Monolaurin and beta carotene combination in the HIV infected people.

Introduce the Monolaurin and Beta-carotene additives to the HIV infected individuals for three months.

The five individuals will be categorized according to their weight and age .

(i) Adult (normal weight) (ii) Under 125 pounds (iii) Over 220 pounds. The weight factor only considered to show how much amount of monolaurin will be consumed by an individual in a day. 


\section{International Journal of Science and Research (IJSR) ISSN (Online): 2319-7064 \\ Index Copernicus Value (2013): 6.14 | Impact Factor (2014): 5.611}

The age factor will be considered for consuming Betacarotene in a day from 14-51+

Individuals should ask for having their CD4 status update before consumption of these medicinal additives.

Their CD4 cell counts will be written on the table for an Adult with normal weight, Under 125 pounds and Over 220 pounds.

An adult will be having normal weight allow to consume 0.5 fl OZ of monolaurin and $900 \mathrm{mcg}$ of $\beta$-carotene per day.

An individual will be having under 125 pounds allow to consume $0.33 \mathrm{fl} \mathrm{OZ}$ and $900 \mathrm{mcg}$ of $\beta$ - carotene per day.

An individual will be having over 220 pounds allow consume $0.66 \mathrm{fl} \mathrm{OZ}$ and $900 \mathrm{mcg}$ of $\beta$ - carotene per day.

Three months later they will be send to have CD4 cell count test and the results will be added on the table. Moreover their blood samples will be collected for High-performance liquid chromatography and other molecular studies.

g) Introduction of Monolaurin and weakened beta carotene combination in the HIV infected people.

Subsequently, after three months the positive individuals will be allowed to consume the combination of Monolaurin and Weakened Beta carotene. This time the beta carotene will be weakened by nicotine ( in the form of smoke or liquid mixture). Here we will use pure nicotine or Nicotine 7.2or $10.0 \% \mathrm{wt} / \mathrm{vol}$ diluted with vegetal glycerine to weakened the Beta carotene. Here also, the CD4 cell counts to be filling in the table for before consumption and after consumption of the monolaurin and weakened betacarotene.

If this effort will not be suitable for the Positive individuals or refused by the individuals we can use humanized mice for this study.

Monolaurin and weakened- beta carotene substances mixed with food and will provide them in a daily basis. $1 \mathrm{mg}$ of monolaurin and $0.8 \mathrm{mg}$ of weakened -Beta carotene / day we can allow them to consume.

h) Combinations of ART, Monolaurin and beta carotene effect on smoker or in the absence of ART.

Monolaurin with beta carotene (Not weakened) combination will be consumed by a person who smokes and will be going for Anti retroviral drugs.Here, the beta carotene will be weakened by the nicotine content in the lungs of the patient. Here, individuals will not have ART but they have the habit of smoking and they will be allowed to consume the Monolaurin and beta-carotene combination.

\section{1) BetaCarotene Determined in Serum by Liquid Chromatography}

The0.1-mLserumsample is precipitated with ethanol containing the internal standard, dimethyl-beta carotene, then extracted with hexane. This extract is injected on to are versed-phase," high-performance" liquid-chromatography column, and the carotenes are resolved an diluted With an acetonitrile/methylene chloride isocratic solvent system. They are quantified from the peak height ratio so for their absorbance at $450 \mathrm{~nm}$. About $14 \mathrm{~mm}$ is required for each chromatogram. The procedure has excellent precision and is appropriate for routine use in analysis of large numbers of samples (William J. Driskell, Mark M. Bashor, and Jane W. Neese).

2) High performance liquid chromatography (HPLC) and R-HPLC to determine the Monolaurin.

HPLC might become the method of choice for determination of emulsifying substances. Most of these substances are UVtransparent (e.g., they contain only saturated fatty acids), and therefore do not contain a chromophoric group to be detected using spectrophotometer UV (Aitzetmuller, 1975). For this reason, emulsifiers are best detected using universal detectors available for HPLC such as evaporative light scattering detection (ELSD), refractive index (RI) and mass spectrometer (MS) (Myher and Kuksis, 1995).

HPLC has been developed for the separation of mono-, di-, and triglycerides of fatty acids on a $25-\mathrm{cm}$ column packed with LiChrosorb DIOL. The glycerides are eluted isocratically with iso-octane-isopropanol $(95: 5 \mathrm{v} / \mathrm{v})$ within I0 min, and the components were detected using UVabsorption at $213 \mathrm{~nm}$ (Riisom and Hoffmeyer, 1978). Liu et al.

A reliable liquid chromatography/atmospheric-pressure chemical ionization mass spectrometry (LC-APCI-MS) method has been developed for the quantitative determination of food emulsifiers composed of MG and DG of fatty acids (E471 series) in complex food matrices by Suman et al (2009). The emulsifiers analyzed are some MGs (monolaurin).

\section{3) BLT mice will be used for this Study}

Construction of BLT mice.Fetal tissue for these studies was obtained from either the UCLA CFAR Gene and Cellular Therapy Core or Advanced Biosciences Resources Inc. SCID-hu (Thy/Liv) mice were generated as previously described using NOD.Cg-Prkde ${ }^{\text {scid }} \mathrm{Il}_{2 \mathrm{rg}^{\text {tm1Wjl }}}$ (NSG) mice. Myeloablation was achieved either by irradiation of mice with 270 rads using a cobalt-60 source or by two injections of $25 \mathrm{mg} / \mathrm{kg}$ (of body weight) busulfan (Sigma) spaced 2 days apart (total, $50 \mathrm{mg} / \mathrm{kg}$ ). This was performed at the time of implantation or at some point over the following 4 months depending on the series. Immediately following ablation, mice were infused via retro-orbital injection with between $10^{5}$ and $10^{6}$ human fetal liver-derived CD $34^{+}$cells, which were isolated as previously described.

Infection procedures and antiretroviral therapy.BLT mice were infected with HIV strain NL4-3 or NLHSAs 2 to 4 months following $\mathrm{CD} 34^{+}$cell infusion depending on the series. Infections will be performed by retro-orbital injection with $50 \mathrm{ng}$ or $200 \mathrm{ng}$ of HIV p24 in a $150-\mu \mathrm{l}$ volume. Briefly, Monolaurin and Weakened- Beta carotene will be added to the drinking water $(\mathrm{pH} 3)$ at concentrations of 1.0 and $0.8 \mathrm{mg} / \mathrm{ml}$, respectively, or it will be administered by daily intraperitoneal injection of $1.8 \mathrm{mg}$ combination /day.

Cell/tissue harvesting.During eye bleeds, a micropipette (VWR) that had been precoated internally with $1.5 \mu \mathrm{l}$ of a

\section{Volume 4 Issue 11, November 2015}




\section{International Journal of Science and Research (IJSR) \\ ISSN (Online): 2319-7064 \\ Index Copernicus Value (2013): 6.14 | Impact Factor (2014): 5.611}

solution composed of 10 parts 500 mM EDTA, 2 parts $25 \%$ human serum albumin (Baxter Healthcare), and 3 parts sterile water was inserted retro-orbitally to remove $50 \mu \mathrm{l}$ of blood. This blood was immediately placed in a tube containing $1 \mu \mathrm{l}$ of $200 \mathrm{mM}$ EDTA and then centrifuged at $845 \times g$ for $5 \mathrm{~min}$. The plasma was removed and stored at $-80^{\circ} \mathrm{C}$ before viral load quantification by reverse transcription (RT)-PCR. Red blood cells in the cell pellet were lysed using ammonium chloride solution (StemCell Technologies) according to manufacturer's guidelines. Peripheral blood mononuclear cells (PBMC) were then used for flow cytometric analysis.

Spleens and Thy/Liv implants were forced through a steel mesh to disaggregate tissue and then passed through a 40$\mu \mathrm{m}$ filter to produce a single cell suspension. For depletion of heat-stable antigen (HSA), the cells were stained with a biotinylated anti-mouse CD24 (HSA) antibody (eBioscience), and then HSA-positive $\left(\mathrm{HSA}^{+}\right.$) cells were depleted using antibiotin microbeads and an auto MACS separator (MiltenyiBiotec) according to the manufacturer's instructions.

\section{4) CD4 cell Count through Flow cytometry}

Immunologic monitoring of HIV-infected patients is a mainstay of the clinical flow cytometry laboratory. The absolute CD4 count provides a powerful laboratory measurement for predicting, staging, and monitoring disease progression and response to treatment in HIV-infected individuals. Quantitative viral load testing is a complementary test for clinical monitoring of disease and is correlated inversely to CD4 counts. However, CD4 counts directly assess the patient's immune status and not just the amount of virus. It is likely that both CD4 T-cell enumeration and HIV viral load will continue to be used for diagnosis, prognosis, and therapeutic management of HIVinfected persons. (Michel brown et al.,)

\section{5) Genotyping test}

These genotyping tests mainly comprise polymerase chain reaction (PCR)-amplification and population, nucleotide sequencing (Sanger methodology) of a large part of the protease (PR), reverse transcriptase (RT), and integrase (IN) genes. using the LDT methodology performed at Janssen Diagnostics BVBA, Belgium (JDx).

\section{6) Statistical method}

The serum of the patient will be detected for the viral load through CD4 cell counts. The combination of Monolaurin and Beta-carotene effects will be correlated with Monolaurin and Weakened -beta carotene combination. HIV/ AIDS with ART drugs takers and HIV/AIDS without ART will be classified in the existing group only. Correlation coefficient between the tables will be framed. NOVA will be constructed for this method with a help of SPSS.

\section{Expected Results}

1) Combinations of monolaurin and beta carotene effect on the HDLs level in the HIV positive

Monolaurin and Beta carotene combinations in the first study will give the result after the Triglyceride test and CD4 cell counts. If the normal triglycerides count will be received or decreased further it shows the content of monolaurinmight to be melt fat with the help of antioxidant properties of beta carotene. HDL level will be increased due to the properties of monolaurin ( derivative of lauric acid) and the cardio vascular problem will be reduced in the HIV patients.

\section{2) Combinations of monolaurin and Weakened beta carotene effect on the viral load control in the HIV positive.}

The second table suggests that the monolaurin combined with the weakened beta carotene due to their solubility nature with fat. Pairing each other and beta carotene facilitates the monolaurin to contact with HIV and the prooxidant properties of beta carotene can alter the RNA bases and it creates Mutation among the base pairs. Properties monolaurin can affect the viral system. This will be studied after the CD4 count test. If the CD4 count will be higher than the previous test it will go for ELISA test.CD4 test will give an idea to investigate the further studies, like CCR5's mutant CCR5- $\Delta 32$ worth to stop the entry of HIV in the host cells. How the viral load will be controlled through these combinations without the involvement of ART, it will support the basic molecular studies.

\section{3) Monolaurin and beta carotene effect on non smokers} in the absence of ART.

B.L Baker et al., (PubMed) identified if smokers will consume more Beta carotene leads to Lung cancer. The result will be expected Combination of Monolaurin and Beta carotene consumed by the smoking individuals but they are supposed to take ART drugs. Here the beta carotene will be weakened by the lungs system due to load of nicotine particles. It shows the pro-oxidant properties with monolaurin and easily contact with the HIV henceforth CD4 count will be tested for further studies. If the CD4 count will be increased due to the Combinationswill be taken for novel studies. Control should be created for ART drug takers that will be not having the smoking habits and not consuming the combinations.

\section{Reasons will be}

1)ART is responsible to increase the CD4 counts but monolaurin and weakened beta-carotene in which way helping the ART. It can easily obtain through to make an individual as a control (Do not provide combinations and he should be a non smoker). The cell counts should be matched with ART-monolaurin- Beta carotene (weakened) Combinations in the smokers and non smoker without consuming combinations.

2)If the CD4 counts increased based on these differentiation the serum of the patients will be analyzed for different molecular studies. Here we will find out molecular level relationship of Monolaurin and Beta carotene. Changes of serum protein will be identified through gel electrophoresis.

\section{Monolaurin and beta carotene effect on smoker}

Here the weakened beta carotene not necessary but the smokers respiratory system could change the normal beta carotene to weakened carotene. The interaction of Beta

\section{Volume 4 Issue 11, November 2015}




\section{International Journal of Science and Research (IJSR) \\ ISSN (Online): 2319-7064 \\ Index Copernicus Value (2013): 6.14 | Impact Factor (2014): 5.611}

carotene with HIV particles with the help of monolaurin in the absence of ART will give a desirable result.

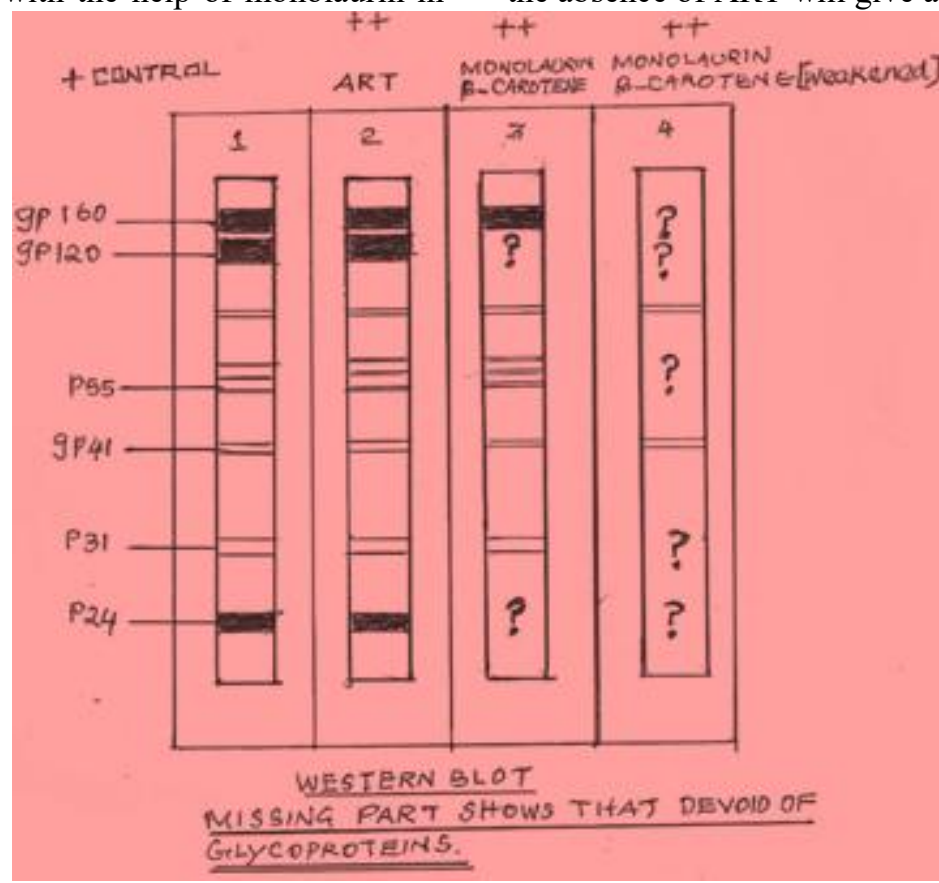

Figure 1.1 shows that Serum collected from HIV positive Individual in various level.

1) HIV Positive serum for control

2) Person who is consuming ART drugs shows the same band pattern with control due to ART only effective in the cell (against reverse transcriptase, integrase, protease) not for proteins

3) Person who will consume the Monolaurin and Beta carotene with or without ART shows that some missing part of glycoprotein, due to monolaurin's viral properties assisted by beta carotene (Antioxidant properties) will damage the viral protein in a decent amount

4) Monolaurin and weakened Beta carotene ( Pro-oxidant properties) can damage more Viral protein.

The missing of glycoprotein gives idea for future studies and prove the action of Drugs.

Table 1: Combinations of monolaurin and beta carotene effect on the HDLs level in the HIV positive.

\begin{tabular}{|c|c|c|c|c|c|c|c|c|c|}
\hline \multirow[t]{4}{*}{ Sample } & \multicolumn{3}{|c|}{$\begin{array}{l}\text { Combination of Monolaurin ( according to weight) and Beta carotene } \\
\text { (according to age) for HIV Positive people }\end{array}$} & \multicolumn{6}{|c|}{$\begin{array}{l}\text { CD4 counts before consumption and after } \\
\text { consumption of Monolaurin and Beta } \\
\text { carotene. }\end{array}$} \\
\hline & Adult (normal weight) & Under 125 pounds & Over 220 pounds & \multirow{2}{*}{\multicolumn{2}{|c|}{ Adult }} & \multirow{2}{*}{\multicolumn{2}{|c|}{$\begin{array}{c}\text { Under } 125 \\
\text { Pounds }\end{array}$}} & \multirow{2}{*}{\multicolumn{2}{|c|}{$\begin{array}{l}\text { Over } 220 \\
\text { Pounds }\end{array}$}} \\
\hline & \multirow[t]{2}{*}{ Age: $14-51+$} & \multirow[t]{2}{*}{ Age: $14-51+$} & \multirow[t]{2}{*}{ Age:14 -51+ } & & & & & & \\
\hline & & & & $\mathrm{B}$ & $\mathrm{A}$ & $\mathrm{B}$ & $\mathrm{A}$ & $\mathrm{B}$ & $\mathrm{A}$ \\
\hline 1 & $\begin{array}{c}3 \text { Scoops }(0.5 \mathrm{fl} \mathrm{OZ})+ \\
900 \mathrm{mcg}\end{array}$ & $\begin{array}{l}2 \text { Scoops }(0.33 \mathrm{fl} \mathrm{OZ})+ \\
900 \mathrm{mcg}\end{array}$ & $\begin{array}{l}4 \text { Scoops }(0.66 \mathrm{fl} \mathrm{OZ})+ \\
900 \mathrm{mcg}\end{array}$ & 100 & 350 & 120 & 380 & 150 & 480 \\
\hline 2 & $\begin{array}{c}3 \mathrm{Scoops}(0.5 \mathrm{fl} \mathrm{OZ})+ \\
900 \mathrm{mcg}\end{array}$ & $\begin{array}{l}2 \text { Scoops }(0.33 \mathrm{fl} \mathrm{OZ})+ \\
900 \mathrm{mcg}\end{array}$ & $\begin{array}{l}4 \text { Scoops }(0.66 \mathrm{fl} \mathrm{OZ})+ \\
900 \mathrm{mcg}\end{array}$ & & & & & & \\
\hline 3 & $\begin{array}{c}3 \text { Scoops }(0.5 \mathrm{fl} \mathrm{OZ})+ \\
900 \mathrm{mcg}\end{array}$ & $\begin{array}{l}2 \text { Scoops }(0.33 \mathrm{fl} \mathrm{OZ})+ \\
900 \mathrm{mcg}\end{array}$ & $\begin{array}{l}4 \text { Scoops }(0.66 \mathrm{fl} \mathrm{OZ})+ \\
900 \mathrm{mcg}\end{array}$ & & & & & & \\
\hline 4 & $\begin{array}{c}3 \text { Scoops }(0.5 \mathrm{fl} \mathrm{OZ})+ \\
900 \mathrm{mcg}\end{array}$ & $\begin{array}{l}2 \text { Scoops }(0.33 \mathrm{fl} \mathrm{OZ})+ \\
900 \mathrm{mcg}\end{array}$ & $\begin{array}{l}4 \text { Scoops }(0.66 \mathrm{fl} \mathrm{OZ})+ \\
900 \mathrm{mcg}\end{array}$ & & & & & & \\
\hline 5 & $\begin{array}{c}3 \text { Scoops }(0.5 \mathrm{fl} \mathrm{OZ})+ \\
900 \mathrm{mcg}\end{array}$ & $\begin{array}{c}2 \text { Scoops }(0.33 \mathrm{fl} \mathrm{OZ})+ \\
900 \mathrm{mcg}\end{array}$ & $\begin{array}{c}4 \text { Scoops }(0.66 \mathrm{fl} \mathrm{OZ})+ \\
900 \mathrm{mcg}\end{array}$ & & & & & & \\
\hline
\end{tabular}

$*(1 \mathrm{fl} \mathrm{OZ}=28.35 \mathrm{~g}) *(1 \mathrm{lb}=453.6 \mathrm{~g}) *(10,000 \mathrm{IU}=0.25 \mathrm{mg})$

$* \quad 1 \mathrm{IU}$ beta-carotene from dietary supplements $=0.15 \mathrm{mcg}$ RAE $* 1 \mathrm{IU}$ beta-carotene from food $=0.05 \mathrm{mcg}$ RAE $* 1 \mathrm{mcg}$ is $=0.001 \mathrm{mg}, \quad * 1 \mathrm{mg}=0.001 \mathrm{~g}$. 


\section{International Journal of Science and Research (IJSR) \\ ISSN (Online): 2319-7064 \\ Index Copernicus Value (2013): 6.14 | Impact Factor (2014): 5.611}

Table 2: Combinations of monolaurin and Weakened beta carotene effect on the viral load control in the HIV positive

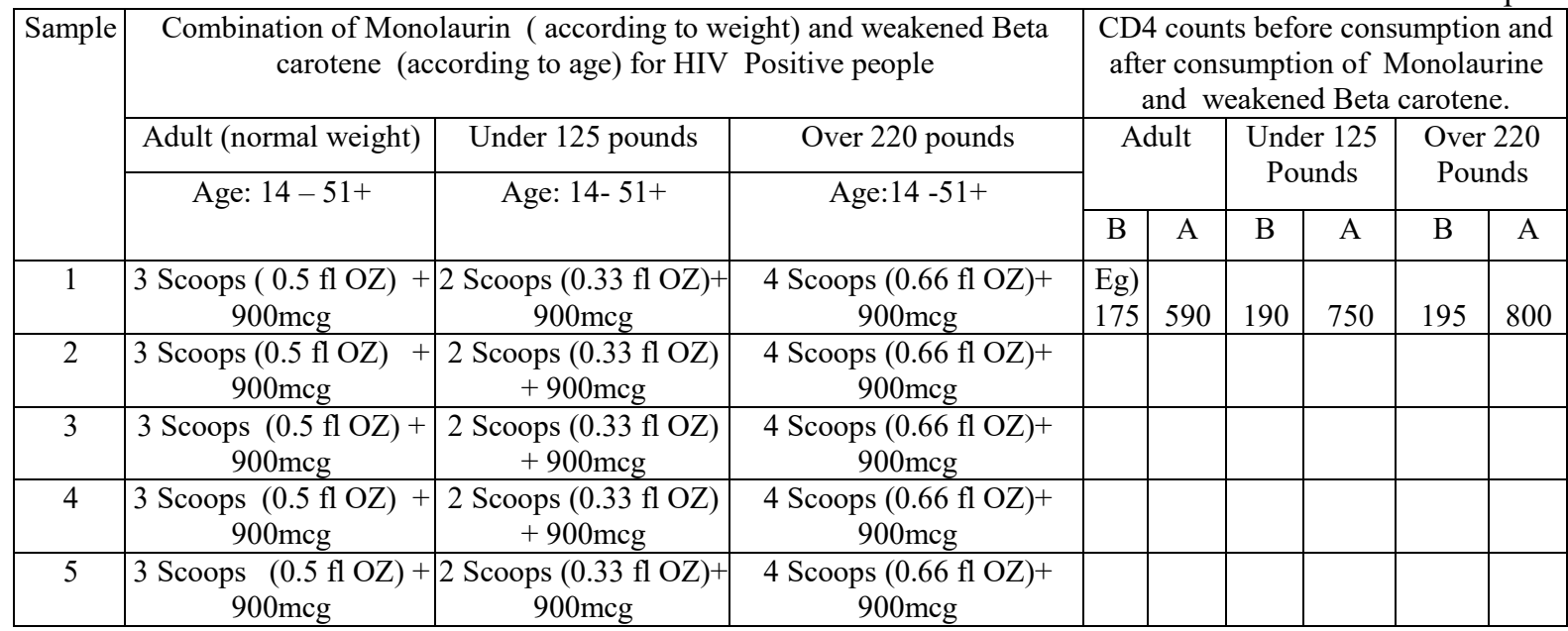

Table 3: Combinations of ART, Monolaurin and beta carotene effect on smoker

\begin{tabular}{|c|c|c|c|c|c|c|c|}
\hline \multirow[t]{2}{*}{ Sample } & \multirow[t]{2}{*}{$\begin{array}{c}\text { ART drugs } \\
\text { takers }\end{array}$} & \multirow[t]{2}{*}{$\begin{array}{l}\text { Smoking } \\
\text { Cigarette }\end{array}$} & \multicolumn{3}{|c|}{$\begin{array}{l}\text { Monolaurin and beta carotene combination/ According to their weight } \\
\text { and age }\end{array}$} & \multicolumn{2}{|c|}{$\begin{array}{l}\text { CD4 Counts in } \\
\text { the cell }\end{array}$} \\
\hline & & & & & & Before & After \\
\hline 1 & Yes & Yes & $\begin{array}{l}3 \text { Scoops }(0.5 \mathrm{fl} \\
\mathrm{OZ})+900 \mathrm{mcg}\end{array}$ & $\begin{array}{l}2 \text { Scoops }(0.33 \mathrm{fl} \mathrm{OZ})+ \\
900 \mathrm{mcg}\end{array}$ & $\begin{array}{l}4 \text { Scoops }(0.66 \mathrm{fl} \mathrm{OZ})+ \\
900 \mathrm{mcg}\end{array}$ & $\begin{array}{l}\text { Eg) } \\
180\end{array}$ & $\begin{array}{l}\text { Eg) } \\
200\end{array}$ \\
\hline 2 & Yes & Yes & $\begin{array}{c}3 \text { Scoops }(0.5 \mathrm{fl} \mathrm{OZ}) \\
+900 \mathrm{mcg}\end{array}$ & $\begin{array}{l}2 \text { Scoops }(0.33 \mathrm{fl} \mathrm{OZ})+ \\
900 \mathrm{mcg}\end{array}$ & $\begin{array}{l}4 \text { Scoops }(0.66 \mathrm{fl} \mathrm{OZ})+ \\
900 \mathrm{mcg}\end{array}$ & & \\
\hline 3 & Yes & Yes & $\begin{array}{l}3 \text { Scoops }(0.5 \mathrm{fl} \\
\mathrm{OZ})+900 \mathrm{mcg}\end{array}$ & $\begin{array}{l}2 \text { Scoops }(0.33 \mathrm{fl} \mathrm{OZ})+ \\
900 \mathrm{mcg}\end{array}$ & $\begin{array}{l}4 \text { Scoops }(0.66 \mathrm{fl} \mathrm{OZ})+ \\
900 \mathrm{mcg}\end{array}$ & & \\
\hline 4 & Yes & Yes & $\begin{array}{l}3 \text { Scoops }(0.5 \mathrm{fl} \\
\mathrm{OZ})+900 \mathrm{mcg}\end{array}$ & $\begin{array}{l}2 \text { Scoops }(0.33 \mathrm{fl} \mathrm{OZ})+ \\
900 \mathrm{mcg}\end{array}$ & $\begin{array}{l}4 \text { Scoops }(0.66 \mathrm{fl} \mathrm{OZ})+ \\
900 \mathrm{mcg}\end{array}$ & & \\
\hline 5 & Yes & Yes & $\begin{array}{l}3 \text { Scoops }(0.5 \mathrm{fl} \\
\mathrm{OZ})+900 \mathrm{mcg}\end{array}$ & $\begin{array}{l}2 \text { Scoops }(0.33 \mathrm{fl} \mathrm{OZ})+ \\
900 \mathrm{mcg}\end{array}$ & $\begin{array}{c}4 \text { Scoops }(0.66 \mathrm{fl} \mathrm{OZ})+ \\
900 \mathrm{mcg}\end{array}$ & & \\
\hline
\end{tabular}

Table 4: Monolaurin and beta carotene effect on smoker in the absence of ART

\begin{tabular}{|c|c|c|c|c|c|c|c|}
\hline \multirow[t]{2}{*}{ Sample } & \multirow[t]{2}{*}{$\begin{array}{c}\text { ART drugs } \\
\text { takers }\end{array}$} & \multirow[t]{2}{*}{$\begin{array}{l}\text { Smoking } \\
\text { Cigarette }\end{array}$} & \multicolumn{3}{|c|}{$\begin{array}{l}\text { Monolaurin and beta carotene combination/According to their weight } \\
\text { and age }\end{array}$} & \multicolumn{2}{|c|}{$\begin{array}{l}\text { CD4 Counts in the } \\
\text { cell }\end{array}$} \\
\hline & & & & & & Before & After \\
\hline 1 & No & Yes & $\begin{array}{c}3 \text { Scoops ( } 0.5 \mathrm{fl} \mathrm{OZ}) \\
+900 \mathrm{mcg}\end{array}$ & $\begin{array}{l}2 \text { Scoops }(0.33 \mathrm{fl} \mathrm{OZ})+ \\
900 \mathrm{mcg}\end{array}$ & $\begin{array}{c}4 \text { Scoops } \\
(0.66 \mathrm{fl} \mathrm{OZ})+900 \mathrm{mcg}\end{array}$ & 148 & 350 \\
\hline 2 & No & Yes & $\begin{array}{c}3 \text { Scoops }(0.5 \mathrm{fl} \mathrm{OZ}) \\
+900 \mathrm{mcg}\end{array}$ & $\begin{array}{l}2 \text { Scoops }(0.33 \mathrm{fl} \mathrm{OZ})+ \\
900 \mathrm{mcg}\end{array}$ & $\begin{array}{l}4 \text { Scoops }(0.66 \mathrm{fl} \mathrm{OZ})+ \\
900 \mathrm{mcg}\end{array}$ & & \\
\hline 3 & No & Yes & $\begin{array}{l}3 \text { Scoops }(0.5 \mathrm{fl} \mathrm{OZ}) \\
+900 \mathrm{mcg}\end{array}$ & $\begin{array}{l}2 \text { Scoops }(0.33 \mathrm{fl} \mathrm{OZ})+ \\
900 \mathrm{mcg}\end{array}$ & $\begin{array}{l}4 \text { Scoops }(0.66 \mathrm{fl} \mathrm{OZ})^{+} \\
900 \mathrm{mcg}\end{array}$ & & \\
\hline 4 & No & Yes & $\begin{array}{l}3 \text { Scoops }(0.5 \mathrm{fl} \mathrm{OZ}) \\
+900 \mathrm{mcg}\end{array}$ & $\begin{array}{l}2 \text { Scoops }(0.33 \mathrm{fl} \mathrm{OZ})+ \\
900 \mathrm{mcg}\end{array}$ & $\begin{array}{l}4 \text { Scoops }(0.66 \mathrm{fl} \mathrm{OZ})^{+} \\
900 \mathrm{mcg}\end{array}$ & & \\
\hline 5 & No & Yes & $\begin{array}{c}3 \text { Scoops }(0.5 \mathrm{fl} \mathrm{OZ}) \\
+900 \mathrm{mcg}\end{array}$ & $\begin{array}{c}2 \text { Scoops }(0.33 \mathrm{fl} \mathrm{OZ})+ \\
900 \mathrm{mcg}\end{array}$ & $\begin{array}{l}4 \text { Scoops }(0.66 \mathrm{fl} \mathrm{OZ})+ \\
900 \mathrm{mcg}\end{array}$ & & \\
\hline
\end{tabular}

\section{References}

[1] Morris DL $\mathrm{Jr}^{1}$, Sutton JN, Harper RG, Timperman AT;Reversed-phase HPLC separation of human serum employing a novel saw-tooth gradient: toward multidimensional proteome analysis.

[2] Van den Eede P1, Van Wesenbeeck L, Verlinden Y, Feyaerts M, Smits V, Verheyen A, Vanhooren L, Deloof A, Villacian J, Pattery T;HIV-1 genotyping of the protease-reverse transcriptase and integrase genes to detect mutations that confer antiretroviral resistance.

[3] Conrado S. Dayrit, MD. FACC.FPCC. FPCP**; COCONUT OIL IN HEALTH AND DISEASE: ITS AND MONOLAURIN'SPOTENTIAL AS CURE FOR HIV/AIDS
[4] Prof Dr Luc Kestens phd; Virology and Immunology of HIV; Source: www.discoverymagazine.com

[5] Kheir-Eldin AA1, Motawi TK, Gad MZ, Abd-elgawad HM; Protective effect of vitamin E, beta-carotene and $\mathrm{N}$-acetylcysteine from the brain oxidative stress induced in rats by lipopolysaccharide ;US National Library of medicine.S ; N Int J Biochem Cell Biol. 2001 May;33(5):475-82 ;

[6] Bai SK1, Lee SJ, Na HJ, Ha KS, Han JA, Lee H, Kwon YG, Chung CK, Kim YM ; beta-Carotene inhibits inflammatory gene expression in lipopolysaccharidestimulated macrophages by suppressing redox-based NF-kappab activation ;J Gen Intern Med. 2002 Oct; 17(10): 797-810. 
[7] Souza SJ1, Luzia LA, Santos SS, Rondó PH; Lipid profile of $\mathrm{HIV}$-infected patients in relation to antiretroviral therapy: a review ; Rev Assoc Med Bras. 2013 Mar-Apr;59(2):186-98

[8] Http //www.inspired nutrition.com

[9] Goralczyk R ; Beta-carotene and lung cancer in smokers: review of hypotheses and status of research. Nutr Cancer. 2009; 61(6):767-74.

[10] PMCID: PMC3920658, NIHMSID: NIHMS505823 ; Free radicbiol Med. Author manuscript; available in PMC 2015 Jan 8. Free radicbiol Med. 2014 Jan 8; 66: 58-64.

[11]Brian J Day, phd ;Antioxidant Therapeutics: Pandora's Box

[12] Sayin VI, Ibrahim MX, Larsson E, Nilsson JA, Lindahl $\mathrm{P}$, Bergo MO; Antioxidants accelerate lung cancer progression in mice; scitransl Med. 2014 Jan 29; 6(221):221ra15

[13] Paul W Denton (et al.,) ; Antiretroviral Pre-exposure Prophylaxis Prevents Vaginal Transmission of HIV-1 in Humanized BLT Mice; DOI: 10.1371/journal.pmed.0050016 ; Published: January 15, 2008

[14] William J. Driskell, Mark M. Bashor, and Jane W. Neese ; Beta-Carotene Determined in Serum by Liquid Chromatography with an; CLIN. CHEM. 29/6, 10421044 (1983) ;1042 CLINICAL CHEMISTRY, Vol. 29, No. 6, 1983

[15] Veronika R. Meyerpractical High-Performance Liquid Chromatography, 5th Edition ISBN: 978-0-470-68218-0 ; 426 pages ; April 2010

[16] Handbook of Flow Cytometry Methods by J. Paul Robinson, et al. ISBN 0-471-59634-5

[17] Flow Cytometry in Clinical Diagnosis, v4, (Carey, mccoy, and Keren, eds), ASCP Press, 2007. ISBN 089189-548-5

[18] Tümmlerb1 ;Genotyping methods ; Methods Mol Biol. 2014;1149:33-47.

[19]J.M. Akey, D. Sosnoski1,E. Parra1, S. Dios1, K. Hiester1,B. Su, C. Bonilla1, L. Jin, and M.D. Shriver; Genotyping Techniques ; Melting Curve Analysis of snps (mcsnpò):A Gel-Free and Inexpensive Approach forsnp Genotyping ; University of Texas houstonhealth Science Center, Houston,TX and 1Penn State University,University Park, PA, USA 